\title{
FUNGSI DAN MULTIKULTURALISME DALAM SENI DIDONG PADA MASYRAKAT GAYO KABUPATEN ACEH TENGAH
}

\author{
Putra Afriadi \\ Program Pascasarjana, Universitas Negeri Semarang \\ E-mail: putraafriadi12@gmail.com
}

\begin{abstract}
Abstrak
Seni Didong berperan besar dalam mempersatukan etnis Gayo yang memiliki berbagai macam pendapat mengenai nilai-nilai moral dan estetika. Didong memiliki fungsi, antara lain: fungsi ekspresi emosional, fungsi tentang kenikmatan estetis, fungsi hiburan, fungsi komunikasi, fungsi representasi simbolis, fungsi respon fisik, fungsi konfornitas terhadap norma-norma sosial, fungsi validasi tentang institusi-institusi sosial dan ritual-ritual keagamaan, fungsi tentang kontribusi terhadap kontinuitas dan stabilitas budaya, fungsi kontribusi terhadap integrasi masyarakat. Masyarakat Gayo harus menyatukan paradigma tentang seni pertunjukan Didong dan Didong Jalu sebagai identitas budaya daerah. Dalam persepektif multikulturalisme, Didong merupakan sebuah sarana untuk menyatukan seluruh etnis yang ada di daerah Gayo, bukan sebaliknya. Didong tidak diklaim sebagai kepemilikan setiap daerah melainkan kepemilikan bersama dan harus dapat menyatukan pemahaman estetika tentang apa yang ada dalam pertunjukan Didong secara keseluruhan, sehingga tidak terjadi kesalah pahaman yang dapat merusak nilai seni dari Didong itu sendiri.
\end{abstract}

Kata kunci: budaya, Didong, Didong Jalu, fungsi, multikulturalisme

\section{FUNCTION AND MULTICULTURALISM IN DIDONG ART IN GAYO SOCIETY OF ACEH CENTRAL DISTRICT}

\begin{abstract}
Didong art plays a major role in unifying the Gayo ethnic who have a wide range of opinions regarding moral and aesthetic values about the existing culture. Didong art has such functions as: emotional expression function, function of aesthetic pleasure, entertainment function, communication function, symbolic representation function, physical response function, conformity function to social norms, validation function of social institutions and religious rituals, functions on contribution to continuity and cultural stability, contribution function to community integration. Gayo society should unify the paradigm about Didong and Didong Jalu performing arts as the cultural identity of the region. In multicultural perspectives, Didong is a means to unite all ethnic groups in the Gayo area, not the other way around. Didong is not claimed as possession of any area but a joint ownership and must be able to unite aesthetic understanding of what is in the Didongshow overall, so there is no misunderstanding that can damage the value of art of Didong itself.
\end{abstract}

Keywords: culture, Didong, Didong Jalu, function, multiculturalism

\section{PENDAHULUAN}

Cara hidup manusia dengan berbagai macam sistem tindakan dijadikan sebagai objek penelitian dan analisis oleh ilmu antropologi sehingga aspek belajar merupakan aspek pokok. Itulah sebabnya dalam hal memberi pembatasan terhadap konsep "kebudayaan" atau culture, ilmu antropologi berbeda dengan 
ilmu yang lain. Kalau dalam bahasa seharihari "kebudayaan" dibatasi hanya pada halhal yang indah (seperti candi, tari-tarian, seni rupa, seni suara, kesustraan dan filsafat. Menurut ilmu antropologi, "kebudayaan" adalah keseluruhan sistem gagasan, tindakan dan hasil karya manusia dalam kehidupan masyarakat yang dijadikan milik diri manusia dengan belajar (Koentjaraningrat, 2009:144). Artinya adalah kebudayaan tersebut merupakan hasil kebiasaan masyarakat, dalam hal ini berupa pemikiran-pemikiran, karya seni sampai pada bentuk bahasa. Kemudian bentuk dari kebudaan itu bertahan sampai sekarang, melalui proses pembelajaran. Oleh karena itu, tradisi selain di temukan juga diciptakan. Dengan demikian bentuk kebudayaan (dalam hal ini seni pertunjukan tradisional) dapat dipahami sebagai kegiatan seni pertunjukan yang memuat nilai dan makna pemikiran, kebiasaan, kepercayaan, norma, adat istiadat untuk diwariskan dari generasi ke generasi.

Argumen tentang kebudayaan tersebut di perkuat oleh ahli-ahli antropologi yang mengungkapkan seni merupakan hasil dari masyarakat itu sendiri. Para ahli antropologi telah menemukan bahwa seni mencerminkan nilai-nilai kebudayaan dan perhatian rakyat. Ini khususnya berlaku untuk kesenian verbal-mitos, legenda dan dongeng-dongeng. Dari sini, para ahli antropologi dapat mengetahui bagaimana suatu bangsa mengatur dunianya, dan mengetahui sejarahnya. Demikian juga, musik dan seni rupa, seperti seni patung, dapat menjadi sarana untuk memahami pandangan dunia seseorang, dan melalui studi distribusional, kesenian dapat memberi gambaran tertentu tentang sejarah suatu bangsa (Haviland, 1988:23).

Berdasarkan kenyataan tersebut penulis akan membahas suatu permasalahan yang terjadi di masyarakat terkait seni perunjukan pertunjukan tadisional masyarakat Gayo, tepatnya di Kabupaten Aceh Tengah yang bernama Didong. Didong merupakan seni tradisi pertunjukan yang berasal dari masyarakat Gayo, dimana Didong menjadi sarana untuk menyampaikan suatu ekspresi masyarakat akan kehidupan keseharian, berisikan pesan kepada generasi muda yang akan datang. Berdasarkan peryataan di atas ada beberapa hal yang menjadi topik pembahasan yaitu, (1). bagaimakah fungsi Didong dalam kehidupan masyarakat Gayo?, dan (2). bagaimanakah Didong dalam konteks multikulturalisme masyarakat Gayo?

\section{PEMBAHASAN \\ Fungsi}

Memecahkan masalah tentang kesenian daerah yang digunakan untuk kegiatan masyarakat telah lama dibicakan oleh berbagai ilmuan antropologi, dalam hal ini merupakan bentuk konsep fungsi kesenian itu di dalam kehidupan masyarakat. A.R. Radcliffe - Brown mengatakan fungsi adalah kontribusi yang dibuat oleh suatu aktivitas tertentu terhadap aktivitas total yang ia merupakan bagiannya. Fungsi dari suatu kebiasaan sosial tertentu adalah kontribusi yang ia buat terhadap kehidupan sosial secar total sebagai pefungsian dari sistem sosial secra total. Pandangan ini mengisyaratkan bahwa sebuah sistem sosial mempunyai satu jenis tertentu tentang kesatuan (unity), yang dapat kita sebut sebagai suatu kesatuan fungsional. Kita bisa mendefenisikannya sebagai suatu kondisi di mana semua bagian dari sistem bekerja bersama dengan suatu tingkat harmoni yang cukup atau konsistensi internal, yaitu tanpa menghasilkan konflik yang permanen yang tidak dapat dipecahkan atau diatur (1952:181) (dalam Alan P. Merriam 2000:282). Pernyatan tersebut memberitahukan kepada kita bahwa fungsi kesenian daerah memiliki kesepakatan dalam hal ini tentang konsistensi fungsi tanpa menimbulkan konflik yang permanen.

Beberapa masalah fungsi terangkum kedalam sepuluh konsep fungsi menurut Alan P.Merriam yaitu :

\section{Fungsi dan ekspresi emosional}

Ada banyak sekali bukti untuk mengindikasikan bahwa fungsi musik sangat luas dan ada banyak sekali level sebagai cara (sarana) eksprsi emosional. Di dalam mendiskusikan tentang teks-teks lagu, kami telah menunjukan bahwa salah satu ciri yang menonjol bagi mereka adalah fakta bahwa mereka menyediakan sebuah sarana untuk mengekspresiakan ide- 
ide dan emosi yang tidak dapat diungkapkan dalam percakapan biasa (Merriam, 2000:294). Pernyatan tersebut membuktikan bahwa, tidak semua informasi, pendapat dan permasalah dapat diungkapkan melalui percakapan, tapi dengan menggunakan seni pertunjukan sebagai medianya.

\section{Fungsi tentang kenikmatan estetis (aesthetic enjoyment)}

Musik dan sebuah estetik adalah jelas berhubungan dengan budaya barat, demikian juga di dalam kebudayaan Arabia, India, China, Jepang, Korea, Indonesia, dan barangkali beberapa negara lain. Tetapi apakah hubungan itu ada di dalam kebudayaan dari dunia terbelakang adalah suatu masalah yang belum jelas. Tercakup disini adalah pertanyaan utama tentang apa sebenarnya eastetik itu, dan khususnya apakah iya merupakan sebuah konsep yang terikat secara budaya. Tidak perlu diragukan, dan ini dapat hanya dikatakan bahwa fungsi dari kenikmatan estetik jelas-jelas ada di dalam beberapa kebudayaan di dunia, dan barang kali ada juga di negara lain (Merriam, 2000:300). Hal ini menunjukan bahwa pemahaman terkait dengan estetik berdasarkan dari kebudayaan yang ada di daerah tersebut.

\section{Fungsi hiburan}

Musik menyediakan sebuah fungsi hiburan di dalam semua masyarakat. Hanya perlu dicatat bahwa sebuah perbedaan barangkali harus dibuat antara "hiburan" yang "murni" yang nampak menjadi suatu ciri khusus dari musik di masyarakat barat, dan hiburan yang dikombinasikan dengan fungsi-fungsi lain (Merriam, 2000:300). Pernyataan tersebut mengajarkan kita bahwa fungsi musik sebagai hiburan dapat dipilah menjadi dua pilihan, hiburan yang memang sebagi "hiburan" atau hiburang sebagai fungsi yang lain.

\section{Fungsi komunikasi}

Kenyataan bahwa musik dimiliki bersama sebagai sebuah aktivitas manusia oleh semua orang bisa bermakna bahwa ia mengkomunikasikan sebuah pemahaman tertentu yang terbatas sekedar oleh karena keberadaanya. Dari semua fungsi musik, fungsi komunikasi barangkali yang paling sedikit diketahui dan dipahami (Merriam, 2000:301). Pernyataan tersebut berkaitan tentang pengalamn estetia seseorang. Kesenia tersebut akan berbeda maknanya bagi setiap penonntonnya, dikarenakn setiap pengalaman sesorang akan seni berbeda-beda.

\section{Fungsi representasi simbolis}

Ada sedikit keraguan bahwa fungsi musik didalam semua masyarakat sebagai sebuah representasi simbolis dari hal-hal lain, ide-ide, dan prilaku (Merriam, 2000:301). Pernyataan ini menunjukan bahwa, barangkali tidak semua kesian merupakan representasi simbolis dari hal lain seperti ide, prilaku, pesan atau makna.

\section{Fungsi respon fisik}

Kenyataan bahwa musik meninggikan respon secara fisik adalah dengan jelas dipandang dalam kegunaannya dalam masyarakat manusia, meskipun respon itu bisa dibentuk melalui konvensi budaya (Merriam, 2000:301). Maksudnya adalah bentuk kesenian daerah memiliki pengaruh terhadap manusia atau masyarakatnya berupa respon fisik, terlepas itu respon negartif atau positif.

\section{Fungsi menguatkan konformitas terhadap norma-norma sosial}

Lagu tentang protes yang meminta perhatian juga untuk membenarkan atau menyalahkan. Penegakan akan konfornitas terhadap normanorma sosial adalah salah satu fungsi utama dari musik (Merriam, 2000:302). Fungsi ini yang seharusnya diketahui oleh masyarakat luas, dimana bentuk seni dalam masyarakat itu menunjukan penegakan akan konfornitas terhadap norma social yang ada dimasyarakat tersebut.

\section{Fungsi validasi tentang institusi-institusi sosial dan ritual-ritual keagamaan \\ Sementara musik digunakan di dalam situasi-situasi sosial dan keagamaan, ada sedikit informasi untuk mengindikasikan serajat}


dimana ia cenderung memvalidasi institusiinstitusi dan ritual-ritual ini. Sistem religius, tervalidasi, sebagaimana didalam folk lore, melalui penjiplakan mitos-mitos dan legenda didalam lagu, dan juga melalui musik yang mengekspresikan persepsi-persepsi religius. Intitusi-institusi sosial tervalidasi melalui lagu-lagu yang menekankan ketepatan dan ketidak tepatan didalam masyarakat, dan juga yang memberitahu manusia apa yang harus dilakukan dan bagaimana melakukannya (Merriam, 2000:302). Artinya adalah, bentuk seni dimasyarakat itu menunjukan identitas dari institusi sosial dan ritual keagamaan yang ada di daerah tersebut, yang nantinya menjadi ciri khas kesenian daerah.

\section{Fungsi tentang kontribusi terhadap kontinyuitas dan stabilitas budaya}

Jika musik memungkinkan ekspresi emosional, memberikan kenikmatan estetis, menghibur, mengkomunikasikan, memunculkan respon fisik, menegakkan konfornitas terhadap norma-norma sosial, dam memvalidasi institusiinstitusi sosial dan ritual-ritual keagamaan, adalah jelas bahwa ia memberikan kontribusi tidak lebih dan tidak kurang dari sembarang aspek kebudayaan yang lain, dan barangkali kami disini menggunakan fungsi dalam pengertian yang terbatas tentang "play a part" (Merriam, 2000:303). Berdasarkan dari apa yang telah dicapai kontribusi semua fungsi seni akan menjadikan seni itu sendiri sebagai stabilitas budaya yang berkelanjutan.

\section{Fungsi kontribusi terhadap integrasi masyarakat}

Musik menyediakan suatu hal dimana anggota-anggota masyarakat berkumpul untuk melakukan aktivitas-aktivitas yang menuntut kerjasama. Tidak semua musik ditampilkan, tentu saja, tetapi setiap masyarakat kadang-kadang diingatkan oleh musik yang menyebabkan anggota-anggotanya bersama dan mengingatkan kembali mereka akan kesatuan mereka (Merriam, 2000:306). Artinya adalah, sebuah kebudayaan tidak akan bertahan apabila tidak dilestarikan bersama, bukan malah sebaliknya.

\section{Multikulturalisme}

Multikulturalisme adalah seperangkat ide atau gagasan yang menghasilkan aliran yang berpandang bahwa terdapat variasi budaya dalam masyarakat, yang terjadi adalah adanya kesetaraan budaya, sehingga antara satu entitas budaya dengan budaya lainnya tidaklah berada dalam suasana bertanding untuk memenangkan pertarungan (Syam, 2009:79). Secara antropologis, menurut Demerath dan Mattheis (2012), dalam masyarakat pluralistik, nilai-nilai multikulturalisme yang terwujud dalam kesadaran bersikap dan berperilaku untuk menghargai dan menerima keanekaragaman atau perbedaan budaya ini penting disosialisasikan atau ditanamkan, karena itu dapat menjadi pengikat persatuan dan kesatuan serta kesetaraan dalam menjalankan kehidupan bermasyarakat, berbangsa, dan bernegara secara demokratis, tanpa prasangka, tidak diskriminatif dan menghargai hak asasi (Mukni dalam Mahfud, 2006; lihat juga Banks dan Banks 2010; dalam Triyanto, 2017). Artinya adalah multikulturalisme menunjukan adanya sikap menghargai berbagai macam etnis budaya. Bukan hanya sekedar menunjukan sikap menghargai, tapi juga sebagai pemersatu antar budaya, ras dan bahasa.

Terdapat tiga sentral multikulturalisme yang dipandang sebagai perspektif tentang kehidupan manusia oleh Bhikhu Parekh (2008), yaitu:

1. Manusia secara kultural dilekatkan dalam posisi bahwa mereka tumbuh dan hidup dalam dunia yang terstruktur secara kultural, mengorganisasikan dan hubunganhubungan social menurut system makna, memposisikan tentang identitas kultural mereka.

2. Kebudayaan-kebudayaan yang berbeda mencerminkan system makna dan jalan pandangan hidup yang baik. Karena masingmasing merelasasikan satu jangkauan terbatas menyangkut kapsitas dan emosi manusia dan menggenggam hanya sebagian dari totalitas eksistensi manusia, masing-masing kebudayaan memerlukan kebudayaan lain untuk memahami dirinya lebih baik, memperluas cakrawala intelektual 
dan moral, mengembangan imajinasi dan melindunginya terhadap gangguangangguan nyata untuk memutlakkan dirinya.

3. Semua kebudayaan kecuali yang paling primitif secara internal bersifat majemuk dan mencerminkan sebuah percakapan berkelanjutan antara tradisi dan rangkaian gagasan mereka yang berbeda-beda.

Kemudian Parekh (2008:443) mengatakan bahwa, apa yang mungkin saya sebut sebagai sebuah perspektif multikultur terdiri dari satu keadaan saling mempengaruhi yang kreatif dari ketiga wawasan yang bersifat komplementer, yakni keterlekatan kultural manusia, keharusan dan keinginan akan keanekaragaman budaya dan dialog antar kebudayaan, dan kemajemukan internal masing-masing budaya. Artinya adalah semua aspek yang meliputi pemikiran masyarakat tentang kebudayaan, baik itu secara moral, dialog antar budaya dan seni, itu menjadi persepektif multikultur dalam kebudayaan yang membuat kita peka terhadap fakta bahwa semua pemikiran kita tentang budaya itu terbatas.

\section{TENTANG MASYARAKAT GAYO DAN KESENIAN DIDONG}

Masyarakat Gayo hidup dalam komuniti kecil yang disebut kampong. Setiap kampong kampong dikepalai oleh seorang gecik. Kumpulan beberapa kampong disebut kemukiman, yang dipimpin oleh mukim. System pemerintahan tradisional berupa unsur kepemimpinan yang disebut sarak opat, terdiri dari reje (raja), petue (petua), imem (imam), dan rayat (rakyat). Pada masa sekarang sebuah kemukiman merupakan bagian dari kecamatan, dengan unsur-unsur kepemimpinan terdiri atas: gecik, wakil gecik, imem, dan cerdik pandai yang mewakili rakyat. Sebuah kampong biasanya dihuni oleh beberapa kelompok belah (klan). Anggota suatu belah merasa berasal dari satu nenek moyang. Masih saling mengenal, dan mengembangkan hubungan tetap dalam berbagai upacara adat. Garis keturunan ditarik berdasarkan prinsip patrilineal. System perkawinan yang berlaku berdasarkan tradisi adalah eksogami belah, dengan adat menetap sesudah menikah yang patrilokal (juelen) atau matrilokal (angkap). Kelompok kekerabatan terkecil disebut sara ine (keluarga inti). Kesatuan beberapa keluarga inti disebut sara dapur. Pada masa lalu beberapa sara dapur tinggal bersama dalam sebuah rumah panjang, sehingga disebut sara umah. Beberapa buah rumah panjang bergabung ke dalam satu belah (klan). Pada masa sekarang banyak keluarga inti yang mendiami rumah sendiri. Pada masa lau orang Gayo terutama mengembangkan mata pencaharian bertani di sawah dan beternak, dengan adat istiadat mata pencaharian yang rumit. Selain itu ada penduduk yang berkebun, menangkap ikan, dan meramu hasil hutan. Mereka juga mengembangkan kerajinan membuat keramik, menganyam, dan menenun. Kini pencaharian dominan adalah berkebun, terutama tanaman kopi. Kerajinan membuat keramik dan anyaman pernah terancam punah, namun dengan dijadikannya daerah ini sebagai daerah salah satu tujuan wisata di Aceh, kerajinan keramik mulai berkembang lagi. Kerajinan lain yang juga banyak mendapat perhatian adalah kerajinan membuat sulaman kerawang dengan motif yang khas (Darmawan, 2010).

Bahasa Gayo merupakan salah satu bahasa dinusantara bagian bahasa Melayu Polinesia, dan dikelompokkan dalam bagian Austronesia. Keberadaan bahasa ini sama dengan keberadaan orang Gayo (urang Gayo). Perkembangan bahasa Gayo tidak terlepas dari persebaran orang Gayo, menjadi beberapa kelompok, yaitu Gayo lut (Kabupaten Aceh Tengah dan Bener Meriah), Gayo Deret yang mendominasi di daerah Isaq Linge dan sekitarnya (masih merupakan bagian wilayah kabupaten Aceh Tengah), Gayo lukup/ serbejadi (Kabupaten Aceh Timur), Gayo Kalul (Aceh Tamiang), dan Gayo Blang (Kabupaten Gayo Lues dan Kabupaten Aceh Tenggara) (Algayoni,2015).

Gayo merupakan salah satu wilayah kebudayaan yang berada di Provinsi Aceh. Sebagai suatu wilayah kebudayaan tentu memiliki warisan budaya yang sampai saat ini masih berkembang di dalamnya. Ketika kita mendekati masyarakatnya, di Gayo perwujudan ekspresi berkesenian masyarakatnya begitu besar. 
Masyarakat Gayo kiranya tidaklah demikian kaya dengan variasi perwujudan artistik berupa hasil kebudayaan material, meskipun mereka mengenal seni arsitektur, ukir, relief, hias, perhiasan. Tampaknya mereka lebih banyak memiliki dan menyenangi berupa kesusastraan seperti puisi, teka-teki, perumpamaan, nyanyian, deklamasi (recitation), legenda dan sebagainya. Oleh karena itu rupanya unsur-unsur kesenian dari luar seperti sa'er, drama, nyanyian, lebih cepat masuknya. Salah satu kesenian yang paling populer di masyarakat Gayo adalah Didong.

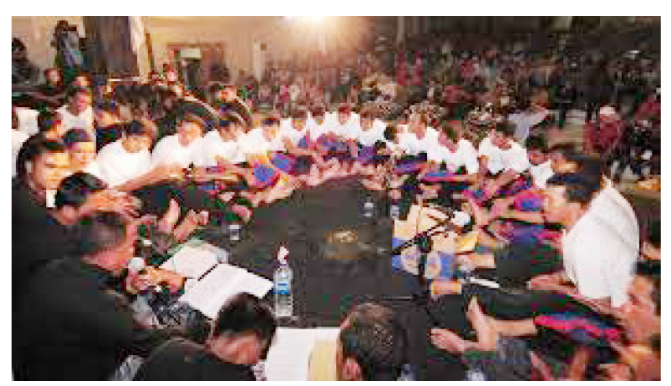

Gambar 1.

Seni pertunjukan tradisional Didong (sumber : www.lintasGayo.com)

Didong juga bisa dinyatakan sebagai salah satu varian dari "nyanyian rakyat" (folksong). Didong memiliki prinsip lisan yang berperan penyampaian pesan moral pada msyarakat luas (Melalatoa,2001:11). Dengan rumusan sederhana, kesenian Didong dapat dinyatakan sebagai konfigurasi ekspresi seni sastra, seni suara, dan seni tari. Pergelaran Didong ini biasa diadakan di tempat atau ruang khusus sebagai pentas, misalnya tempo dulu di ruang luas rumah panggung (umah sara); di atas panggung buatan pada ruang terbuka, misal di halaman, lapangan dan lain-lain. Pentas ini tentunya dilengkapi dengan sarana penerangan, mulai dari yang sederhana seperti api unggun, petromak atau lampu listrik pada masa-masa terakhir ini. Keseluruhan pemain dilengkapi dengan bantal kecil (kampas) sebagai alas tepukan-tepukan tangan yang menjadi ritme bagi melodi dalam kesenian ini. Anggota satu kelop terkadang memakai baju seragam yang biasa disebut sebagai baju-kelop, sedangkan aktor utamanya biasanya memakai atribut tambahan berupa syal yang dililitkan di leher dan ada yang memakai kopiah. Di antara sejumlah unsur seni bertutur yang terangkum dalam seni Didong adalah: Kekitiken/Ure-ure (seni berteka-teki). Yaitu seni dalam berteka-teki yang biasanya dilakukan oleh anak-anak menjelang tidur. Dari segi bahasa dan kalimat yang digunakan dalam teka-teki ini lebih mementingkan tata bunyi dan irama dengan pola persajakan a-b a-b. Seni berteka-teki ini merupakan bentuk puisi Gayo yang telah cukup tua. Berikut Seni berteka-teki dalam Didong secara keseluruhan:

1 Kekeberen (prosa lisan). Kekeberen adalah salah satu bentuk prosa yang disampaikan secara lisan yang mendapat tempat luas dalam masyarakat Gayo di masa silam. Seperti halnya dengan Didong, prosa ini biasanya dituturkan pada malam hari menjelang tidur. Si pencerita mungkin seorang nenek kepada cucunya atau oleh orang senior lainnya. Di antara tema-tema itu adalah tentang cinta, patuh kepada orang tua, akal bulus, ketauladanan dan lain sebagainya.

2 Melengkan (seni pidato adat). Yaitu pidatopidato adat dalam berbagai kesempatan upacara, masyarakat Gayo melahirkan rasa seninya dalam bentuk kata-kata puitis. Pidato adat ini dilakukan secara berbalasbalasan dan oleh pendengarnya dapat dirasakan kalah atau menang.

3 Sebuku (seni meratap). Pengungkapan perasaan yang terjalin dalam puisi-puisi tertentu yang umumnya hanya dilakukan oleh kaum wanita. Isi dari puisi sebuku biasanya mengungkapkan hal-hal yang bersifat sedih.

Berikut contoh lirik lagu dalam kesenian Didong:

Didong Didong o Didong ni Didong ko ken seni ni urang Gayo ni Tekek-tekek teles basa Bijak cerdek totor kata Roneng tekek maken gaya Osop macek pora-pora

Didong Didong Didong ken ingeten Ku ate bersuen kusiremi 


\author{
Tiep ate tiep jantong \\ Beloh sabe kao nonong \\ Ngeh bertape ngeh bertarong \\ Berketebong jantong rasa \\ Didong Didong Didong ngemutoron \\ Nge berlape salon ari jemen mi \\ Surak surak bererie \\ Sara sintak I sedenge \\ Kaol kucak tue mude \\ Songoh gure umah sara \\ Didong denang Didong denang kudenang \\ Berketebong iwan ni jantong \\ Berjunte iwan ni ate \\ Berketebong iwan ni jantong \\ Berjunte iwan ni ate
}

(terjemahan dalam bahasa Indonesia)

Didong didong o didong

Didong kau untuk keseniannya orang Gayo

Sedikit-sedikit terlihat jelas

Bijak cerdik bertutur kata

Roneng sedikit makin gaya

Hilang khawatir pelan-pelan

Didong didong didong sebagai ingatan

Ke hati bersua kusiramkan

Setiap hati setiap jantung

Pergi selalu kau mengikuti

Sudah menetap sudah bertarung

Bergemuruh rasa jantung

Didong didong didong sudah turun

Sudah ada dari jaman dahulu

Sorak sorak bereriak

Satu di bumi

Merangkul kecil, muda dan tua

Sangat nyaman satu rumah

Didong lagu didong lagu didong kulagukan

Bergemuruh di dalam jantung

Berjuntai di dalam hati

(sumber: azmira.wordpress.com)

Lirik lagu di atas dinyanyikan dan dipadukan dengan tepukan tangan sebagai iringannya, berikut contoh dari motif-motif tepukan (tepok) Didong yang ditunjukan melalui transkripsi notasi:

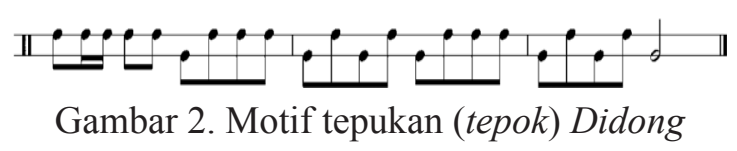

Didong adalah seni pertandingan antara dua kumpulan atau grup yang masing-masing disebut ulu (kelop) (melalatoa,2001:2). Didong itu sendiri memiliki bentuk pertunjukan yang lain yang dinamakan Didong Jalu. Biasanya Didong Jalu dimainkan oleh dari masing-masing kelop berjumlah sekitar 30 pemain. Mereka terbagi atas dua kategori utama, yaitu ceh dan penunung atau penyur (pengiring) (Melalatoa,2001:11). Seorang yang bisa disebut ceh harus memenuhi syarat. Modal utamanya adalah suara merdu (ling temas). Suara merdu saja tidak cukup, ia pun harus punya kemampuan menciptakan lirik atau puisi (kekata) sendiri, yang akan ditembangkan dengan model melodi ciptaan sendiri tadi. Ia harus punya pengetahuan yang luas perihal latar belakang adat istiadat (edet) masyarakatnya dengan segala perkembangan atau perubahan yang terjadi dan juga pengetahuan tentang lingkungan lain yang lebih luas. Pengetahuan luas ini harus berimbang dengan kekayaan perbendaharaan kata, ungkapan, simbol-simbol pikiran, sehingga lahirlah lirik-lirik indah dengan bobot pesan yang dalam, tajam, aktual, tapi juga ajek. Karya dengan bobotnya yang ajek itu berarti sebuah lirik menyimpan pandangan yang menjadi bahan renungan bahkan menjadi acuan dalam kehidupan masyarakatnya.

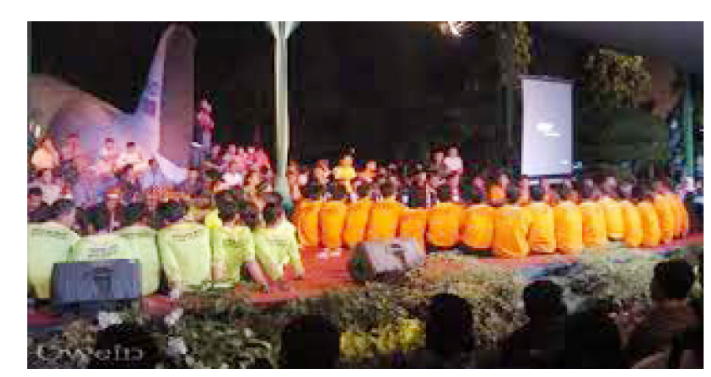

Gambar 3 : Didong Jalu

(sumber: uwein.wordpres.com)

Dalam sistem pertandingan Didong jalu itu sendiri, seorang ceh juga dituntut memiliki kemampuan mencipta lirik-lirik yang diciptakan secara spontan (munapak), suatu hasil 
improvisasi dan kreativitas di tengah arena pertandingan yang tengah berlangsung. Liriklirik spontan dan mendadak adalah kemampuan luar biasa yang terlahir oleh sistem pertandingan Didong jalu itu, yang tidak sembarangan orang (ceh) memilikinya. Di sinilah hasil ekspresi pikir dan rasa terjelma. Kemampuan ini akan dinilai oleh penonton dan terlebih lagi oleh para juri yang akan memberi kata keputusan "menang atau kalah" pada akhir pertandingan di pagi hari. Dalam setiap kelop biasanya punya dua sampai tiga "pasang" ceh yang tampil berduet atau kadang-kadang trio. Jarang sekali ceh bersenandung sendiri (solo) kecuali dalam menyenandungkan melodi untuk lirik sebuah ratapan (sebuku). Salah satu dari ceh itu adalah ceh utama atau aktor utama (ceh kul, kul=besar), sedangkan pasangannya atau partner dalam berduet atau trio itu disebut apit. Pasangan (duet atau trio) lainnya biasa disebut ceh due (due=dua) atau aktor pembantu yang dalam pertandingan berperan membantu ceh kul dalam menghadapi serangan atau menyerang lawan tanding. Ceh kul memiliki suara termerdu dibanding ceh lain dalam sebuah kelop, pencipta melodi dan lirik terbaik, menjadi pemikir, penyusun strategi untuk merebut simpati penonton, serta menjaga semangat "juang" para pengiringnya. Sebuah kelop berjaya atau kalah dalam setiap malam pertandingan lebih banyak ditentukan oleh kebolehan ceh kul. Seorang ceh Didong jalu di tanoh Gayo, selain mampu menciptakan lirik Didong, juga harus memiliki suara yang bagus, dan mampu membawakan lirik-lirik tadi (menjadi vokalis Didong). Namun, dewasa ini banyak ceh yang tidak memenuhi syarat. Lebih banyak ceh-ceh-han. Umumnya ceh sekarang, hanya mampu membawakan lirikan Didong. Itu pun karya ceh lain, yang sudah kerap dibawakan dalam Didong, atau lagu. Belum lagi, suaranya yang pas-pasan. Ceh yang ada sekarang cenderung memaksakan diri, asal disebut ceh. Banyak ceh tidak lagi mampu mencipta, terlebih lagi dengan kandungan nilai-nilai, dan filsafat sastra Gayo yang tinggi. Salah seorang ceh Didong, Latif, menyebutkan, "Enti mu lelang empus si nge lapang”, yang artinya, jangan membersihkan rerumputan (yang ada di) kebun yang sudah lapang. Sebaliknya, harus mampu menciptakan karya sendiri, tidak plagiat, dan tidak mengklaim karya orang lain jadi milik sendiri. Didong Jalu merupakan seni pertunjukan tradisional yang berfungsi sebagai upaya untuk menyampaikan suatu nasihat kepada masyarakat. Lewat Didong masyarakat bebas berekpresi. Kemudian ada suatu ketika kesenian ini berubah menjadi petunjukan tradisional yang digunakan untuk kepentingan berpolitik. Menggunakan Didong sebagai media untuk menarik rakyat banyak agar memilih calon pemimpin. Dalam pertunjukannnya, seperti yang dijelaskan sebelumnya bahwa Didong berisikan pesan yang baik unuk generasi muda, tapi berubah menjadi pesan untuk masyarakat setempat yang berisikan bujukan atau rayuan untuk memilih pemimpin, dan isi pesannya juga sering menjelekkan calon pemimpin yang lain. Hal tersebut sangat disayangkan sebab pertunjukan tradisional yang semestinya menjadi bahan untuk menyampaikan wasiatwasiat atau pesan-pesan kepada generasi muda ini dirusak hanya untuk kepentingan pribadi.

Pernah pada suatu kejadian, pada saat pertunjukan Didong Jalu terjadi keributan yang menyebabkan perkelahian antar warga. Berawal dari sebuah nyanyian yang berisi pesan yang tidak senonoh untuk calon pemimpin maka pihak lain yang tidak suka dengan hal tersebut memberontak dan akhirnya menyebabkan keributan, sampai pada akhirnya pertunjukan Didong Jalu dibubarkan demi kenyamanan bersama. Beberapa hal dari kejadian tersebut sangat disayangkan, pasalnya banyak yang melihat pertunjuan terdiri dari anak-anak kecil. apakah baik bagi mereka melihat bentuk pertunjukan seni yang seharusnya menjadi bahan pelajaran mereka, untuk hidup yang lebih baik digunakan untuk hal-hal yang bersifat pribadi. Coba kita pikirkan kembali, dampak yang terjadi pada anak-anak masyarakat setempat, anak-anak sangat mudah mengaplikasikan hal-hal yang baik ataupun buruk pada kehidupan sehariharinya. Pada masa sekarang ini Didong Jalu sudah jarang sekali dipertunjukan, bahkan anakanak sekarang tidak tahu apa yang dinamakan Didong Jalu, seperti apa pertunjukannya, 
bagaimana kesenangannya dalam melakukan satu pertunjukan Didong Jalu.

\section{FUNGSI DAN MULTIKULTURALISME DALAM KESENIAN DIDONG}

Fungsi

Didong merupakan seni tradisi pertunjukan yang berasal dari masyarakat Gayo, dimana Didong menjadi sarana untuk menyampaikan suatu ekspresi masyarakat akan kehidupan keseharian, berisikan pesan kepada generasi muda yang akan datang. Kesenian ini banyak sekali mempengaruhi masyarakat Gayo dalam kesehariannya, seperti membawa semangat kedalam hidup masyarakatnya. Lirik lagu yang menarik dalam bentuk sejenis prosa, pantun yang mengelitik hati, tatkala sering menjadi bahan candaan dalam masyarakat Gayo. Didong biasanya di pertunjukan pada acara-acara resmi seperti setelah pesta pernikahan, peringatan hari besar daerah. Maka hal tersebut akan dikaji kedalam beberapa bentuk fungsi yakni:

\section{Didong sebagai Fungsi dan ekspresi} emosional

Didong sebagai bentuk kebudayaan masyarakat Gayo merupakan luapan ekspresi emosional yang dialami oleh masyarakat Gayo. Menunjukan bentuk dari pola pikir tentang kebudayaan daerah, kemudian hasil pemikiran tersebut diekspresikan kedalam bentuk kesenian yang sampai saat ini terus bertahan dan menjadi spirit untuk masyarakat Gayo. Ungkapan ekspresi melalui Didong bisa dalam bentuk apa saja, misalnya sebagai sebagai pertunjukan untuk menarik masyarakat lain untuk mengunjungi daerah dalam hal ini sebagai ajang promosi, kemudian dalam bentuk protes terhadap kebijakan pemerintah daerah, teguran halus untuk generasi muda yang lebih mementingkan budaya luar daripada melestarikan budaya sendiri. Karna ungkapan yang ada didalam hati masyarakat tidak semuanya dapat diungkapkan melalui kata-kata atau pembicaraan, melalui Didong lah masyarakat dapat mengungkapkan ekspresi mereka dengan bebas.

\section{Didong sebagai Fungsi tentang kenikmatan estetis (aesthetic enjoyment)}

Berbicara tentang estetik berarti berbicara tentang pengalaman seseorang, sejauh apa orang tersebut memandang fenomena yang ada meliputi budaya atau hal lainnya. Dalam hal ini kesenian Didong, pemahaman estetik tentang Didong itu sendiri berdasarkan dari masyarakat daerah Gayo itu sendiri. Maksudnya adalah apabila ada masyarakat lain yang melihat pertunjukan kesenian Didong maka pemahaman pertama kali yang mereka pikirkan adalah kesenian itu merupakan perwujudan dari budaya masyarakat Gayo itu sendiri, baik dari moral, sosial, dan adat istiadat.

\section{Didong sebagai Fungsi hiburan}

Sudah tidak diragukan lagi bahwa Didong menjadi sara hiburan bagi masyarakat Gayo. Hal ini ditunjukan dari pertunjukan Didong yang kerap memuat isi lirik yang menggelitik hati masyarakat Gayo, biasanya isi bersifat sindiran halus terkait fenomena masyarakat Gayo itu sendiri, misalnya seperti fenomena anak kecil yang mengerti tentang pacaran dirangkai sedemikian rupa kedalam Didong, sehingga banyak masyarakat yang mendengarnya tertawa. Namun dalam hal ini ada dua bagian yang perlu digaris bawahi, hiburan untuk benar-benar hibura dan hiburan yang memiliki nilai. Dalam fungsi sebgai hiburan semata hanyalah berupa ekspresi dari masyarakat terkait fenomena yang ada sedangkan fungsi hiduran yang memiliki nilai adalah Didong yang didalamnya mengandung pesan adat istiadat daerah.

\section{Didong sebagai fungsi komunikasi}

Sebagai fungsi komunikasi, Didong pada awal pertunjukan sangat sulit untuk dipahami dan dimengerti, hal ini ditunjukan pada isi lirik yang memakai pantun atau prosa tua dalam adat istiadat masyarakat Gayo, namun dimasa sekarang banyak isi dari lirik Didong difariasikan kedalam bahasa Indonesia yang menjadikan masyarakat lain selain orang Gayo dapat menikmati keindahan yang ada didalam seni Didong tersebut. 


\section{Didong sebagai fungsi representasi simbolis}

Didong dari awalnya merupakan representasi simbolis dari masyarakat Gayo dan adat istiadatnya. Menjadi ungkapan dari ide-ide dan moral yang ada dalam masyarakat Gayo, terus bertahan sampai sekarang. Memang tidak semua bentuk seni merupakan representasi simbolis, namun untuk Didong, hal ini jelas merupakan representasi simbolis dari seluruh aspek dan ruang lingkup kebudayaannya.

\section{Didong sebagai fungsi respon fisik}

Didong merupakan bentuk kesenian daerah yang memiliki pengaruh terhadap manusia atau masyarakatnya berupa respon fisik, terlepas itu respon negartif atau positif. Bentuk respon yang paling Nampak adalah dari aspek instrument yang digunakan pada saat pertunjukan berlangsung, seperti seragam, banyak pemain, sampai pada lirik, dipengaruhi oleh beberapa kelompok dan kemudian menyebar dan akhirnya menjadi standar penampilan Didong itu sendiri.

\section{Fungsi menguatkan konfornitas terhadap norma-norma sosial}

Sebagai fungsi ini, sangat jelas sekali Didong menjadi penguat konfornitas terhadap norma-norma social yang ada dikalangan masyarakat Gayo. Pada awal pembahasan telah dikatakan bahwa Didong merupakan ekspresi budaya yang disalurkan melalui karya seni yang berisikan nilai-nilai budaya dan adat istiadat masyarakat Gayo.

\section{Fungsi validasi tentang institusi-institusi sosial dan ritual-ritual keagamaan}

Sebagai seni yang menjadi cirikhas daerah, Didong memvalidasi faktor keagaamaan masyarakat Gayo. Hal ini ditunjukan dari sekian banyaknya lirik Didong terdapat beberapa lirik yang menyatakan puji-pujian terhadap Tuhan Yang Maha Esa, dikarenakan mayoritas mayarakat Gayo adalah Islam. Mengayunkan badan pada salah satu bagian dari Didong seperti berzikir pada orang islam.

\section{Fungsi tentang kontribusi terhadap kontinyuitas dan stabilitas budaya}

Berdasarkan dari apa yang telah dicapai, kontribusi semua fungsi seni akan menjadikan seni itu sendiri sebagai stabilitas budaya yang berkelanjutan. Dalam hal ini, Didong menjadi kontribusi yang paling besar dalam kontinyuitas dan stabilitas budaya, dikarenakan Didong merupakan identits budaya masyarakat Gayo.

\section{Fungsi kontribusi terhadap integrasi masyarakat}

kebudayaan tidak akan bertahan apabila tidak dilestaraikan bersama, bukan malah sebaliknya. Didong sebagai bentuk dari budaya dari masyarakat Gayo hendaknya dilestarikan tanpa merusak nilai-nilai dan norma yang ada pada Didong tersebut, jangan sampai digunakan untuk kepentingan yang merusak kaedah seni seni sebagai hasil dari kebudayaan itu.

\section{Multikulturalisme}

Masyarakat yang multikulturalisme tidak terikat oleh doktrin apapun dan visi hidup yang baik dan mempertanyakan seberapa besar keanegaragaman itu, karena dalam konteks pespektif multikulturalisme hal tersebut akan membuat kita terbatasi dengan aturan-aturan yang dibuat oleh setiap kelompok. Masyarakat Gayo sendiri memiliki beberapa etnis yaitu alas, deret dan loet. Masing-masing dari etnis tersebut memiliki seninya masing-masing, namun hanya ada satu seni yang dapat merangkul dan menyimbolkan kepemilikan dari seluruh etnis yaitu Didong. Didong bukan milik dari Gayo alas, deret maupun loet tetapi milik semua etnis Gayo. Dalam persepektif multikulturalisme, Didong merupakan sebuah sarana untuk menyatukan seluruh etnis yang ada di daerah Gayo.

Manusia secara kultural dilekatkan dalam posisi bahwa mereka tumbuh dan hidup dalam dunia yang terstruktur secara kultural, mengorganisasikan dan hubungan-hubungan social menurut system makna, memposisikan tentang identitas kultural mereka (Parekh, 2008:440). Dalam hal ini Didong merupakan hasil dari kebudayaan yang dibuat sedemikian 
rupa yang memiliki hubungan-hubungan social dengan masyarakat Gayo secara umum, merupakan identitas kultural masyarakat Gayo.

Kebudayaan-kebudayaan yang berbeda mencerminkan system makna dan jalan pandangan hidup yang baik. Karena masingmasing merelasasikan satu jangkauan terbatas menyangkut kapasitas dan emosi manusia dan menggenggam hanya sebagian dari totalitas eksistensi manusia, masing-masing kebudayaan memerlukan kebudayaan lain untuk memahami dirinya lebih baik, memperluas cakrawala intelektual dan moral, mengembangan imajinasi dan melindunginya terhadap gangguan-gangguan nyata untuk memutlakkan dirinya (Parekh, 2008:441). Perbedaan etnis mencerminkan system makna dan pandangan yang baik. Masing-masing memiliki intensitas budaya yang berbeda-beda, cara pandang yang berbedabeda. Setiap pertunjukan dari etnis yang ada di daerah Gayo menggunakan caranya tersendiri, terutama pada bagian lirik lagu yang digunakan, Gayo alas akan membuat lirik sesuai dengan bahasa mereka, sedangkan Gayo deret juga membuat lirik sesuai dengan bahasa sehari-hari yang mereka gunakan, begitu juga dengan etnis Gayo yang lain. Setiap etnis saling mempengaruhi, sehingga menjadikan sebuat pemikiran dan wawasan yang luas, saling bertukar pikiran melalui pertunjukan Didong. Sehingga tercapailah kesetaraan secara menyeluruh mengenai kepercayaan diri, kekuatan ekonomi dan akses menuju masyarakat Gayo secara keseluruhan.

Semua kebudayaan kecuali yang paling primitif secara internal bersifat majemuk dan mencerminkan sebuah percakapan berkelanjutan antara tradisi dan rangkaian gagasan mereka yang berbeda-beda (Parekh, 2008:442). Perbedaanperbedaan dari pihak lain akan membuka wawasan kita, memecah kemajemukan internal masing-masing kebudayaan. Dalam hal ini kegunaan Didong Jalu sebagai sarana untuk mengkapanyekan pemilihan pemerintahan. Hal tersebut dilakukan untuk memberikan pendapat (terlepas dari positif dan negatif) tentang calon yang akan dipilih. Dalam pertunjukan Didong
Jalu, setiap kelompok akan saling mengadu pantun, prosa dan liriknya juga berisikan pesan atau pujian untuk calon pemimpin daerah. Namun dampak yang paling negative dari pertunjukan ini adalah kurangnya estetika masyarakat untuk melihat pertunjukan itu. Jika apa yang dimaksudkan malah dianggap lain bagi masyarakat atau pasangan dari calon yang akan menciptakan perseteruan, dan hal ini jelas menyalahi system multikultural. Seharusnya dengan adanya pertunjukan tersebut masyarakat dapat melihat ciri-ciri pemimpin yang baik untuk memimpin, bukan sebaliknya, memilih pemimpin dari hasil pertunjukan yang menjelekjelekkan pemimpin yang lain. Namun sekarang hal ini sudah jarang dilakukan, mengingat beberapa kejadian yang tidak menguntungkan. Bukan hanya dalam sarana pemilihan, pada perlombaan juga pernah terjadi kesalah pahaman estetika pertunjukan. Seharusnya kita sebagai masyarakat yang pluralistik dapat mengapresiasi hal tersebut, karena apa? Banyak kalangan muda yang sudah tidak mau melakukan pertunjukan Didong Jalu. Mungkin hal tesebut dikarenakan efek yang ditimbukan setelah melakukan pertunjukan berdampak negative kemasyarakat.

Sekarang paradigma tentang pertunjukan Didong Jalu oleh pemuda adalah tentang siapa yang menang, asusmsinya bisa apa saja, menang karena kelompok yang lain kehabisan akal untuk "meladeni" pantun yang berisikan sindiransindiran halus, walaupun itu sudah meliputi aspek penilaian tentang seberapa bagus lagu yang dibuat, seberapa bagus variasi tepokan pada grup tersebut, semangat dan kekompakannya. Inilah yang membuat masyarakat multikultur sulit untuk ditata, mereka tidak perlu mengalami mimpi buruk politis dan bahkan mungkin bisa menyenangkan jika kita menghilangkan kekhawatiran tradisional kita yang panjang dengan suatu pemerintahan yang homogen secara kultural dan struktur dengan ketat, dan bukannya membiarkan masyarakat tersebut menganut bentuk-bentuk kelembagaan, bentuk pemerintahan, serta keutamaan-keutamaan politik dan moral milik mereka yang pantas (Parekh, 2008:450). Mereka perlu menemukan 
cara-cara menggabungkan tuntutan yang sah mengenai kesatuan dan keanekaragaman pemahaman estetika tentang Didong dan Didong Jalu, menjunjung tinggi nilai budaya yang ada agar hasil dari kebudayaan ini tidak hilang dari waktu ke waktu.

\section{KESIMPULAN}

Kebudayaan tersebut merupakan hasil kebiasaan masyarakat, dalam hal ini berupa pemikiran-pemikiran, karya seni sampai pada bentuk bahasa. Kemudian bentuk dari kebudaan itu bertahan sampai sekarang, melalui proses pembelajaran. Oleh karena itu, tradisi selain di temukan juga diciptakan. Dengan demikian bentuk kebudayaan (dalam hal ini seni pertunjukan tradisional) dapat dipahami sebagai kegiatan seni pertunjukan yang memuat nilai dan makna pemikiran, kebiasaan, kepercayaan, norma, adat istiadat untuk diwariskan dari generasi ke generasi.

Khususnya seni pertunjukan Didong, sebagai hasil dari kebudayaan Gayo, Didong berperan besar dalam mempersatukan etnis Gayo yang memiliki berbagai macam pendapat mengenai nilai-nilai moral dan estetika tentang budaya yang ada. Didong juga memiliki fungsi diantara lain : fungsi ekspresi emosional, fungsi tentang kenikmatan estetis, fungsi hiburan, fungsi komunikasi, fungsi representasi simbolis, fungsi respon fisik, fungsi konfornitas terhadap norma-norma social, Fungsi validasi tentang institusi-institusi sosial dan ritual-ritual keagamaan, Fungsi tentang kontribusi terhadap kontinyuitas dan stabilitas budaya, Fungsi kontribusi terhadap integrasi masyarakat.

Masyarakat Gayo harus menyatukan paradigma tentang seni pertunjukan Didong dan Didong Jalu sebagai identitas budaya daerah. Dalam persepektif multikulturalisme, Didong merupakan sebuah sarana untuk menyatukan seluruh etnis yang ada di daerah Gayo, bukan sebaliknya. Didong tidak diklaim sebagai kepemilikan setiap daerah melainkan kepemilikan bersama. Harus dapat meyatukan pemahaman estetika tentang apa yang ada dalam pertunjukan Didong secara keseluruhan, sehingga tidak terjadi kesalah pahaman yang dapat merusak nilai seni dari Didong itu sendiri.

\section{DAFTAR PUSTAKA}

Algayoni, Yusradi Usman. 2015. "Pelestarian Bahasa Gayo”. Jurnal: Serambi Indonesia 2015.

Darmawan, 2010. "Peranan Sarak Opat Dalam Masyarakat Gayo”. Jurnal: Kanun No.50 Edisi April 2010.

Haviland, Wiliam A. 1988. "Antropologi: Jilid 2". Jakarta : Erlangga.

Koentjaraningrat. 2009. "Pengantar Ilmu Antropologi". Rineka Cipta.

Melalatoa, M. Junus. 2001. "Didong Pentas Kreativitas Gayo”. Jakarta. Yayasan Obor Indonesia

Merriam, Alan P. 2000. "Antropologi Musik (Terjemahan)". Universitas Negeri Semarang. Semarang. 2000.

Parekh, Bikhu. 2008. "Rethingking Multikulturalisme, Keberagaman Budaya Dan Teori Politik". Yogyakarta : Impulse dan Kanisius.

Syam, Nur. 2009. “Tantangan Multikulturalisme Indonesia". Yogyakarta : Impulse Dan Kanisius.

Triyanto. 2017. "Spirit Ideologis Pendidikan Seni”. Semarang: Cipta Prima Nusantara. 